\title{
The Relation Between Multifocality and Clinical, Pathological and Histological Results in Renal Tumors
}

\author{
Böbrek Tümörlerinde Multifokalitenin Klinik, \\ Patolojik ve Histolojik Bulgularla İlişkisi
}

\section{Bahadir Ermec $^{1}$ (D, Metin Ishak Ozturk ${ }^{2}$ (D, Bilal Eryildirim ${ }^{3}$ (D), Erbil Ergenekon ${ }^{4}$ (1)}

\begin{abstract}
'Department of Urology, University of Health Sciences, Prof. Dr. Cemil Tascioglu City Hospital, Istanbul, Turkey
${ }^{2}$ Department of Urology, University of Health Sciences, Haydarpasa Numune Training and Research Hospital, Istanbul, Turkey

${ }^{3}$ Department of Urology, University of Health Sciences, Dr. Lutfi Kirdar Training and Research Hospital, Istanbul, Turkey

${ }^{4}$ Department of Urology, University of Health Sciences, Sisli Hamidiye Etfal Training and Research Hospital, Istanbul, Turkey
\end{abstract}

Cite as: Ermec B, Ozturk MI, Eryildirim B, Ergenekon E. The relation between multifocality and clinical, pathological and histological results in renal tumors. Grand J Urol 2022;2(1):1-7.
Submission date: 21 June 2021
Acceptance date: 06 October 2021
Online First: 11 October 2021
Publication date: 20 January 2022
Corresponding Author: Bahadir Ermec / University of Health Sciences, Prof. Dr. Cemil Tascioglu City Hospital, Department of Urology, Istanbul, Turkey / drbahadir76@hotmail.com / ORCID ID: 0000-0002-7680-9119

\begin{abstract}
Objective: In this study, histological, pathological and clinical characteristics that may affect multifocality rate and multifocality in renal tumors were investigated.

Materials and Methods: A total of 162 patients who underwent radical nephrectomy with the diagnosis of renal tumor from our urology clinic and urology clinics in two other hospitals between May 2002 and April 2006 and whose results were available were included in the study. Kidney samples were evaluated regarding multifocality through sections made macroscopically at an interval of $3 \mathrm{~mm}$.

Results: Of the patients included in the study, $92(56.8 \%)$ were male and $70(43.2 \%)$ were female. The mean age of the patients was 59.98 years $(22-87)$. In $11(6.7 \%)$ of 162 patients, a multifocality focus was pathologically observed. Satellite lesions were radiologically identified in two (18.2\%) of the patients with multifocality. On the other hand, satellite lesions could not be identified radiologically in nine patients (5.5\%). Univariate and multivariate analyzes were performed to determine the relation between pathological, histological, and clinical characteristics and multifocality. There was no significant relation between age, gender, smoking, the location of the tumor, pathological stage, lymph node involvement, the presence of metastasis, the size of the tumor, and histology of the tumor. Univariate analysis results showed a statistically significant relation between renal capsule involvement and renal vein involvement and multifocality ( $\mathrm{p}=0.015$ and $\mathrm{p}=0.004$, respectively); however, only renal capsule involvement was found to be associated with multifocality in multiple logistic regression analysis $(\mathrm{p}=0.008)$.

Conclusion: In our multicentric study including 162 patients, the multifocality rate in renal tumors was $6.7 \%$ (11 patients). There was a significant relationship between capsule involvement and multifocality $(\mathrm{p}=0.015-\mathrm{p}=0.008$ ). Meta analysis is required to determine the rate of multifocality in renal tumors and identify with which clinical, pathological, and histological characteristics it is associated.
\end{abstract}

Keywords: renal tumor, radical nephrectomy, multifocality

$\ddot{\mathrm{O} z}$

Amaç: Biz bu çalışmamızda, böbrek tümörlerinde multifokalite oranını ve multifokaliteyi etkileyebilecek histolojik, patolojik ve klinik özellikleri araştırdık Gereçler ve Yöntemler: Mayıs 2002- Nisan 2006 tarihleri arasında üroloji kliniğimiz ve diğer iki hastanedeki üroloji kliniklerinden böbrek tümörü tanısı ile radikal nefrektomi yapılan ve bulgularına ulaşılan 162 hasta çalışmaya alındı. Böbrek spesmenleri makroskobik ve 3 mm'lik aralıklarla ince kesit yapılarak multifokalite açısından değerlendirildi.

Bulgular: Çalışmaya alınan hastaların 92'si (\%56,8) erkek, 70’i (\%43,2) kadındı. Hastaların ortalama yaşları 59,98 (22-87) idi. 162 hastanın 11'inde (\%6,7) patolojik olarak multifokalite odağı görüldü. Multifokalite belirlenen hastaların 2'sinde (\%18,2) radyolojik olarak satellite lezyon saptandı. Buna karşılık 9 hastada (\%5.5) radyolojik olarak satellite lezyon saptanamadı. Patolojik, histolojik ve klinik özelliklerin multifokalite ile olan ilişkisini saptamak için univariate ve multivariate analizler yapıldı. Hasta yaşı, cinsiyet, sigara kullanımı, yerleşim yeri, patolojik evre, lenf nodu tutulumu, metastaz varlığı, tm boyutu, tm histolojisi arasında anlamlı bir ilişki saptanmadı. Univariate analiz sonucu hem renal kapsül tutulumu hem de renal ven tutulumu ile multifokalite arasında istatistiki anlaml ilișkili saptanırken (sırasiyla $\mathrm{p}=0,015$ ve $\mathrm{p}=0,004)$, multipl logistic regression analizinde sadece renal kapsül tutulumu multifokalite ile ilişkili olarak bulundu ( $\mathrm{p}=0,008)$.

Sonuç: Multisentrik, 162 vakalık çalıșmamızda böbrek tümörlerinde multifokalite sıklığını 11 hasta $(\% 6,7)$ olarak saptadık. Bizim çalıșmamızda kapsül tutulumu $(\mathrm{p}=0,015-\mathrm{p}=0,008)$ ile multifokalite arasında anlamlı bir ilişki bulunmuştur. Böbrek tümörlerinde multifokalite oranının ve hangi klinik, patolojik ve histolojik özelliklerle ilişkili olduğunun saptanması için meta-analize ihtiyaç vardır.

Anahtar kelimeler: böbrek tümörü, radikal nefrektomi, multifokalite
ORCID ID: M.I. Ozturk
0000-0001-9369-8206
B. Eryildirim
0000-0002-2213-3985
E. Ergenekon
0000-0002-6806-2473

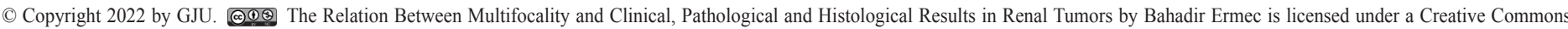

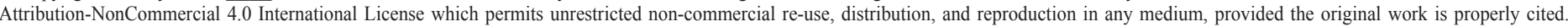




\section{Introduction}

Currently, renal cell carcinoma (RCC) represents about 3\% of all cancers and the highest incidence occurs in Western countries [1]. High duration of survival achieved by radical nephrectomy, made this method the gold standard in the treatment of earlystage renal tumors. However, in a surgery to be performed in patients with a solitary kidney, chronic renal failure, or a systemic disease that will affect contralateral renal function, or who have bilateral tumors, the intact kidney should be preserved. Achieving a longer survival that is comparable to radical nephrectomy in nephron-sparing surgery (NSS), which means removing the tumor by sparing the most functional parenchyma, and the improvements in surgical technique (development of prevention methods against ischemic renal damage, increased renal vascular surgery experience) have increased the interest in this method [2]. Moreover, the indications of NSS have enlarged with the application of partial nephrectomy in small, early-stage, peripherally located, and incidentally detected renal tumor cases [3].

Partial nephrectomy has the disadvantage that it may cause local recurrence due to the inability to remove the satellite tumor in multifocal cases, as well as the advantages of preventing the removal of the entire kidney with benign tumors and reducing the risk of long-term renal failure [4,5].

There is no precise information about the biological potential of these multifocal microscopic residual tumors [6]. The multifocality rate in renal cortical tumors was within a wide range of $4.7 \%-25 \%$ in various studies [7-16]. In this multicentric study including 162 patients, the histological, pathological and clinical characteristics that may affect the multifocality rate and multifocality in renal tumors were analyzed.

\section{Materials and Methods}

\section{Patient Selection}

The study was approved by the Institutional Review Board Ethics Committee of Istanbul Training and Research Hospital (Approval no: 2021/2911). An informed consent was obtained from all the patients. A total of 210 patients who underwent surgery between May 2002 and April 2006 with the diagnosis of renal tumor from our urology clinic and urology clinics in two other hospitals were retrospectively evaluated. Radical Nephrectomy was performed in 178 of 210 patients, and nephron-sparing (partial) nephrectomy was performed in the remaining 32 patients. The patients who underwent partial nephrectomy were excluded from the study. Moreover, 16 of the patients who underwent radical nephrectomy were excluded from the study as some information was missing. None of the patients were excluded from the study based on primary tumor size and the TNM classification. A total of 162 renal tumor patients who underwent radical nephrectomy were included in the study and their preoperative-peroperativepostoperative results were analyzed.

\section{Clinical Evaluation}

All of the 162 patients diagnosed with renal tumor were evaluated based on an anamnesis (age, gender, occupation, initial complaint, and smoking), a complete physical examination, complete urinalysis, hemogram, sedimentation, urea-creatinine ratio, liver-function tests, calcium, ferritin, chest radiography, abdominal ultrasonography (US), and computed tomography (CT). In addition, abdominal magnetic resonance imaging (MRI), MR angiography, and Doppler USG were performed in some patients for differential diagnosis, clinical staging, and surgery method. Based on these data, the patients were clinically staged according to the 2002 tumour-node-metastasis (TNM) classification.

The patients were staged by taking the TNM classification as a reference following the pathological examination, and they were included in the follow-up protocol.

\section{Pathological Evaluation}

All kidney samples were evaluated by a pathologist in the pathology clinics of the hospitals included in the study according to the same protocol developed (Table 1). Accordingly, the samples were first examined macroscopically for primary tumor size and the presence of satellite lesions. Then, multifocality was investigated through thin sections made at $3 \mathrm{~mm}$ intervals on the samples. Histological classification of the primary tumor and the satellite tumor was made according to the Union for International Cancer Control (UICC) and the American Joint Committee on Cancer (AJCC). The differential diagnosis of adenoma and carcinoma was made histologically. Accordingly, histologically papillary masses of $\leq 5 \mathrm{~mm}$ with a low Fuhrmann nuclear grade were accepted as adenoma. Adenomas were not considered multifocal lesions and were not included in the study.

\section{Statistical Analysis}

Demographic results and distribution of tumor characteristics of the patients were compared using the Chi-Square Test. Univariate and multivariate analysis were performed using logistic regression to determine the relation between clinical and pathological characteristics and multifocality. Variables included patient age, gender, smoking history, primary tumor size, the location of the tumor, pathological stage (pT), lymph node involvement, the presence of distant metastasis, capsule involvement, renal vein involvement, and histological diagnosis.

\section{Results}

Of the patiens included in the study, $92(56.8 \%)$ were male and $70(43.2 \%)$ were female. The mean age of the patients was $59.98(22-87)$. In $11(6.7 \%)$ of the 162 patients, the multifocality focus was observed pathologically. The demographic results and tumor characteristics of the patients are shown in Table 2. Satellite lesions were identified radiologically in $2(18.2 \%)$ of the 11 patients with multifocality. Both of these satellite lesions were demonstrated by a CT scan and/or MRI. The rate of multifocality (occult) that could not be diagnosed with preoperative imaging was 9 patients $(5.5 \%)$ in 162 patients.

When all renal tumors were examined histologically using 
Table 1. Multifocality in renal tumors (A multi-center study)

NAME-SURNAME:

\begin{tabular}{|c|c|c|c|c|}
\hline Age: & Profession: & & & \\
\hline Phone: & Address: & & & \\
\hline COMPLAINT: & & & & \\
\hline Hematuria: & Mass: & Weight loss: & Anemia: & Pain: \\
\hline Polycythemia: & Hypertension: & Hepatic Dysfunction: & Other: & \\
\hline
\end{tabular}

\section{LABORATORY:}

Hb: Hct: Leucocyte: Urea: Creatinine: SGOT: SGPT:

Calcium: Ferritin:

USG: Right Kidney:

Left Kidney:

IVP: Right Kidney:

Left Kidney:

CT: Right Kidney:

Left Kidney:

MR: Right Kidney:

Left Kidney:

Chest radiography:

Other Imagings:

CLINICAL STAGING: cT: cN: cM:

METHOD OF SURGERY:

Suspected macroscopic satellite lesion noticed during the surgery (cortical irregularity):

\section{MACROSCOPY:}

Kidney weight:

Other:

Tm Size:

Necrosis:

Kidney sizes: $\quad \mathrm{x} \quad \mathrm{x} \quad \mathrm{cm}$

Histopathology:

Tm type: $\quad$ Clear cell ( ) Papillary ( ) Chromophobe ( ) Collecting tubules ( ) Medullary ( )

Nuclear Grade: $\quad$ Grade 1 ( ) Grade 2( ) Grade 3 ( ) Grade 4 ( )

Renal capsule involvement:

Renal vein invasion:

Surgical margins: $\quad$ Ureteral ( ) Renal vein ( ) Soft tissue ( ) Adrenal ( ) Lymph nodes ( )

PATHOLOGICAL STAGING: $\mathrm{pT}$ : $\mathrm{pN}$ : $\mathrm{pM}$ :

MULTIFOCALITY:

Number: Size: $\quad$ Nuclear Grade: $\quad$ Grade1 ( ) Grade2 ( ) Grade3 ( ) Grade4 ( )

Histological type:

Distance to the primary: Location: Subcapsular ( ) Intraparenchymal ( )

NOTE OF PATHOLOGY: When the renal capsule is peeled off, the cortex is examined, if possible, for irregular areas under magnification, and the intraparenchymal lesion is investigated with serial sections of $1 \mathrm{~cm}$ and then $3 \mathrm{~mm}$ following taking the necessary samples for the primary tumor.

the UICC and AJCC classification systems, it was identified that $106(65.4 \%)$ had conventional clear cell carcinoma, 32 (19.8\%) had papillary cell carcinoma, 9 (5.6\%) had chromophobe cell, five $(3.1 \%)$ had oncocytoma, two $(1.2 \%)$ had collecting tubules carcinoma, two $(1.2 \%)$ had medullary cell carcinoma, and six (3.7\%) patients had unclassifiable type renal cell carcinoma. On the other hand, five patients $(45.5 \%)$ had papillary cell carcinoma, five (45.5\%) had conventional clear cell carcinoma, and one (9\%) had chromophobe cell carcinoma concerning multicentric tumors. Discordance was observed in two patients (18.2\%) between primary renal tumor and satellite lesion histology; these were chromophobe-papillary and clear cell-papillary cell carcinoma. There was no discordance between primary tumor grade and satellite tumor grade in any patient.

The tumor size was mean $8.12 \mathrm{~cm}(2 \mathrm{~cm}$ to $17 \mathrm{~cm})$ in primary tumors. Radical nephrectomy was performed for tumors smaller than $4 \mathrm{~cm}$ because it is completely endophytic and close to the collecting system. Tumor sizes regarding multifocality and unifocality were mean $7 \mathrm{~cm}(2 \mathrm{~cm}-12 \mathrm{~cm})$ and $8.01 \mathrm{~cm}(2 \mathrm{~cm}-$ $17 \mathrm{~cm}$ ), respectively. Multifocality was identified in nine patients 
Table 2. Demographic characteristics and pathological-histological results of the patients with renal tumors

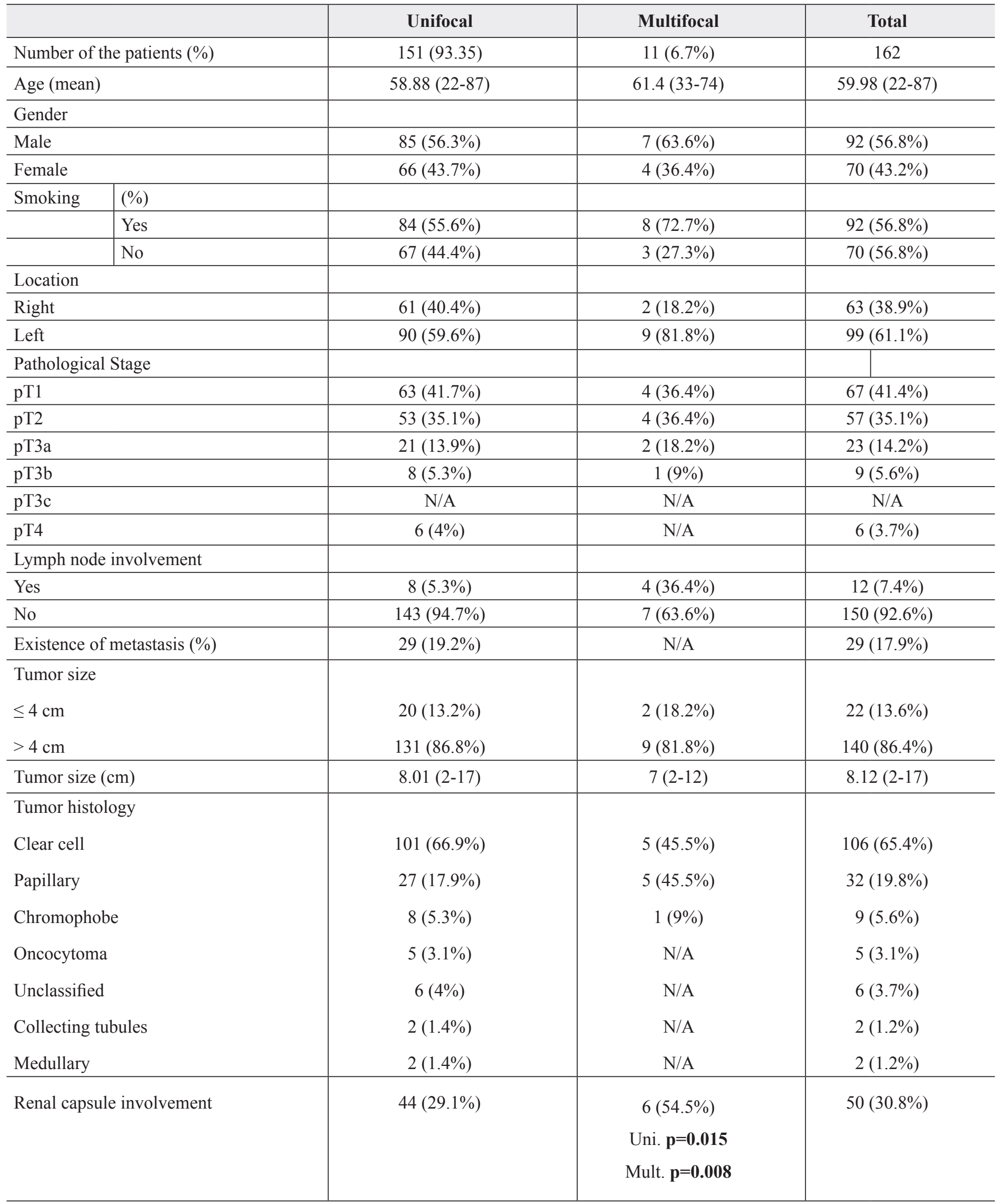


(4.3\%) among 140 samples with a primary tumor size of $>4 \mathrm{~cm}$, and in two patients (9\%) among 22 samples with a primary tumor size of $\leq 4 \mathrm{~cm}$. While $>4$ multifocality foci were observed in two patients, four foci in one patient, three foci in one patient, two foci in four patients, one focus in three patient were observed. The mean distance of satellite lesions to the primary tumor was $1.33 \mathrm{~cm}(0.2-3.5)$.

When the distribution of primary tumors, according to the 2002 TNM classification, was analyzed, the frequency was T1 in 67 patients $(41.4 \%)$, T2 in 57 patients $(35.1 \%)$, T3a in 23 patients $(14.2 \%), \mathrm{T} 3 \mathrm{~b}$ in 9 patients $(5.6 \%)$, and T4 in six patients $(3.7 \%)$. In 12 patients $(7.4 \%)$, lymph node positivity was identified, and metastasis was identified in 29 patients $(17.9 \%)$ at the time of admission. In patients with multifocality, the distributions for T1, T2, T3a, and T3b were four $(36.4 \%)$, four $(36.4 \%)$, two $(18.2 \%)$, and one $(9 \%)$, respectively. Multifocality was not identified in any of the six T4 patients. There was lymph node positivity in four $(36.4 \%)$ of 11 multifocal tumors. None of the patients with multifocality were metastatic at the time of diagnosis.

Univariate and multivariate analyzes were performed to determine the relation between pathological, histological, and clinical features and multifocality. While univariate analysis results showed a statistically significant relation between both renal capsule involvement and renal vein involvement and multifocality $(\mathrm{p}=0.015$ and $\mathrm{p}=0.004$, respectively), only renal capsule involvement was associated with multifocality in multiple logistic regression analysis $(\mathrm{p}=0.008)$.

\section{Discussion}

There are limited data about sporadic cases in the literature, though well defined in hereditary renal cell carcinomas, such as multifocal renal cortical tumors, Von Hippel Lindau (VHL) syndrome, hereditary renal papillary carcinoma, familial oncocytoma, and Birt-Hogg Dubé (BHD) syndrome. The multifocality rate in renal cortical tumors was in a wide range of $4.7 \%-25 \%$ in various studies [7-16]. In a study with the largest series on this subject, Siracusano et al. identified a multifocality rate of 5\% in 5378 renal cortical tumors [15]. The lower rate, compared to other series, may be attributed to the retrospective nature of the study, though being with a large series, and the pathological examination performed through routine pathological evaluation rather than $3 \mathrm{~mm}$ thin-section examination. In addition, studies with higher rates were the series with a maximum of 108 patients [9-13]. In our study, multifocality was identified in 11 $(6.7 \%)$ of 162 patients.

The difference between adenoma and RCC in terms of the differential diagnosis in these studies investigating multifocality may also explain the discordance in the multifocality rates. Some pathologists make adenoma diagnosis based on the size of the mass and the limit is determined as $3 \mathrm{~cm}[11,12]$. However, as in the criteria of the present study, many pathologists make the differential diagnosis of adenoma and RCC based on the histological characteristics of tissues.

It is possible to show satellite lesions with imaging methods such as CT, MRI, and USG performed during preoperative period. Kletscher et al. identified multifocality using a preoperative CT scan and/or MRI in 44\% of their patients [10]. However, the rates were $14 \%$ and $23 \%$ in the studies by Baltaci et al. and Schlichter et al., respectively $[13,18]$. In the present study, two $(18.2 \%)$ of 11 patients with multifocality were diagnosed using preoperative imaging methods. The rates of multifocality (occult) that could not be diagnosed using preoperative imaging methods were between $3.5 \%$ and $29 \%$ in the same studies [10-14,16,17]. This rate was identified in $9(5.5 \%)$ of 162 patients in the present study.

In some studies, a significant relationship was shown between various histological, pathological, and clinical features and multifocality [9-15]. In our study, there was no statistically significant difference between primary tumor histology and multifocality, and it was observed to be associated especially with papillary type renal cell carcinoma. There are contradictory results in the literature regarding the relation between tumor histology and multifocality. There was no statistically significant relation in the studies of Whang et al., Baltaci et al. and Sargin et al. $[11,13,16]$. Kletscher et al., Richstone et al. and Siracusano et al. found a significant relation between papillary renal cell carcinoma and multifocality $[10,14,15]$. When we examined the histological structure of renal tumors, we found that papillary type renal cell carcinoma was more common in multifocal samples than unifocal samples. However, Richstone et al. showed in their 1071 disease series that the distribution of histological subtypes in the multifocal group was also similar to that of the unifocal group [14]. The discordance between the primary tumor and satellite lesion histology was $18.2 \%$ (6-30\%), which was similar to the studies in the literature.

The relation between tumor size and multifocality has been the most interesting point in the studies of multifocality as nephronsparing surgery is performed in peripherally-located renal tumors of $<4 \mathrm{~cm}$ in current urology practice. In a series of 100 patients, Kletscher et al. identified multifocal foci in 16 samples $(16 \%)$, while the tumor size was $<4 \mathrm{~cm}$ in 8 of these 16 samples $(50 \%)$ [10]. Mukamel et al. found the rate of patients with a primary tumor at a diameter of $<4 \mathrm{~cm}$ in multifocal tumors as $31 \%$, which supported the results of the study by Kletscher et al. [9]. Baltaci et al. identified the rate as $32 \%$, and it was identified as $39 \%$ by Richstone et al. $[13,14]$. In the present series, the rate was $18.2 \%$. These rates explain the reason for local recurrence that develops after partial nephrectomy performed in peripherally-located tumors with a size of $<4 \mathrm{~cm}$.

Although it was considered to be a relation between tumor stage and multifocality, Kletscher and Gohji could not identify this correlation in their studies $[10,12]$. However, Richstone et al. Baltaci et al. showed that there was a significant relation between the stage and multifocality $[13,14]$. Siracusano et al. also showed that high stage and high tumor grade were associated with multifocality [15]. The results of other studies suggested that the tumor stage was associated with multifocality; however, the relation was not statistically significant $[9,11,12]$. In our series, there was no significant relation between the tumor stage and multifocality.

In prospective studies in the literature, the total renal tumor sample has usually been $\geq 100$; however, investigating the correlation of multifocality with clinical, pathological, and histological characteristic may yield different results as the number of samples with multifocality is a maximum of 22. However, in a study with the largest series (5378 patients) Siracusano et al. 
could not obtain sufficient results due to both retrospective design of the study and not making examination with a thin section of 3 $\mathrm{mm}[15]$.

The limitations of our study include its retrospective multicenter study. In addition, the relatively small sample sizes may lead to a higher heterogeneity of the research. Therefore, determining the multifocality rate in renal tumors and clinical, pathological, and histological parameters associated multifocality with meta-analysis will provide more reliable data.

\section{Conclusion}

In our multicentric study including 162 patients, we determined the multifocality rate as $6.7 \%$ (11 patients) in renal tumors. Although various clinical, pathological, and histological characteristics were associated with multifocality, a significant relation was found between capsule involvement $(\mathrm{p}=0.015-$ $\mathrm{p}=0.008$ ) and multifocality, especially in the present study. Metaanalysis is required to determine the rate of multifocality in renal tumors and identify with which clinical, pathological, and histological characteristic it is associated.

Ethics Committee Approval: The study was approved by the Institutional Review Board Ethics Committee of Istanbul Training and Research Hospital (Approval number: 2021/2911).

Informed Consent: An informed consent was obtained from all the patients.

Publication: The results of the study were not published in full or in part in form of abstracts.

Peer-review: Externally and internally peer-reviewed.

Authorship Contributions: Any contribution was not made by any individual not listed as an author. Concept - B.E., M.I.O., B.E., E.E.; Design - B.E., E.E., B.E., M.I.O.; Supervision -B.E., M.I.O., B.E., E.E.; Resources - B.E., M.I.O., B.E.; Materials -B.E., M.I.O., B.E., E.E.; Data Collection and/or Processing B.E., M.I.O., B.E., E.E.; Analysis and/or Interpretation -B.E., B.E., M.I.O.; Literature Search - B.E., M.I.O., B.E.; Writing Manuscript - B.E., M.I.O., B.E.; Critical Review - B.E., E.E.

Conflict of Interest: The authors declare that they have no conflict of interest.

Financial Disclosure: The authors declare that this study received no financial support.

\section{References}

[1] Ferlay J, Colombet M, Soerjomataram I, Dyba T, Randi G, Bettio M, et al. Cancer incidence and mortality patterns in Europe: Estimates for 40 countries and 25 major cancers in 2018. Eur J Cancer 2018;103:356-87.

https://doi.org/10.1016/j.ejca.2018.07.005.

[2] Van Poppel H, Da Pozzo L, Albrecht W, Matveev V, Bono A, Borkowski A, et al. A prospective, randomised EORTC intergroup phase 3 study comparing the oncologic outcome of elective nephron-sparing surgery and radical nephrectomy for low-stage renal cell carcinoma. Eur Urol 2011;59:543-52.

https://doi.org/10.1016/j.eururo.2010.12.013.
[3] Kural AR, Demirkesen O, Akpınar H. Düşük evreli böbrek tümörlerinde nefron koruyucu cerrahi. In: Solok V, Erözenci NA, editors. Ürolojide ikilemler, İstanbul: Doyuran Matbaas1; 1997, p. 98-105.

[4] McKiernan J, Yossepowitch O, Kattan MW, Simmons R, Motzer RJ, Reuter VE, et al. Partial nephrectomy for renal cortical tumors: pathologic findings and impact on outcome. Urology 2002;60:1003-9.

https://doi.org/10.1016/s0090-4295(02)01967-2.

[5] McKiernan J, Simmons R, Katz J, Russo P. Natural history of chronic renal insufficiency after partial and radical nephrectomy. Urology 2002;59:816-20.

https://doi.org/10.1016/s0090-4295(02)01501-7.

[6] Kovacs G, Akhtar M, Beekwith BJ, Bugert P, Cooper CS, Delahunt B, et al. The Heidelberg classification of renal cell tumours. J Pathol 1997;183:131-3.

https://doi.org/10.1002/(SICI)1096-9896(199710)183:2\%3C131::AIDPATH931\%3E3.0.CO;2-G.

[7] Karadeniz T, Güzelburç V, Şahin S, Beşiroğlu H. The Relationship of Multifocality With Prognostic Factors in Renal Cell Carcinoma. Okmeydanı Tip Dergisi 2012;28:35-41. https://www.researchgate.net/publication/315044129 .

[8] Kuzgunbay B, Soyupak B. Böbrek tümörlerinde multifokalite. Neye dikkat etmeli? Bull Urooncol 2010;9:6-8. http://cms.galenos.com.tr/Uploads/Article_8364/6-8.pdf.

[9] Mukamel E, Konichezky M, Engelstein D, Servadio C. Incidental small renal tumors accompanying clinically overt renal cell carcinoma. J Urol 1988;140:22-4. https://doi.org/10.1016/s0022-5347(17)41474-1.

[10] Kletscher BA, Qian J, Bostwick DG, Andrews PE, Zincke $\mathrm{H}$. Prospective analysis of multifocality in renal cell carcinoma: influence of histological pattern, grade, number, size, volume and deoxyribonucleic acid ploidy $\mathrm{J}$ Urol 1995;153:904-6.

https://pubmed.ncbi.nlm.nih.gov/7853571/.

[11] Whang M, O'Toole K, Bixon R, Brunetti J, Ikeguchi $\mathrm{E}$, Olsson CA, et al. The incidence of multifocal renal cell carcinoma in patients who are candidates for partial nephrectomy. J Urol 1995;154:968-71.

https://pubmed.ncbi.nlm.nih.gov/7637103/.

[12] Gohji K, Hara I, Gotoh A, Eto H, Miyake H, Sugiyama T, et al. Multifocal renal cell carcinoma in Japanese patients with tumors with maximal diameters of $50 \mathrm{~mm}$ or less. J Urol 1998;159:1144-7.

https://pubmed.ncbi.nlm.nih.gov/9507818/.

[13] Baltaci S, Orhan D, Soyupek S, Bedük Y, Tulunay O, Gögüs O. Influence of tumor stage, size, grade, vascular involvement, histological cell type and histological pattern on multifocality of renal cell carcinoma. J Urol 2000;164:36-9. https://pubmed.ncbi.nlm.nih.gov/10840419/.

[14] Richstone L, Scherr DS, Reuter VR, Synder ME, Rabbani F, Kattan MW, et al. Multifocal renal cortical tumors: Frequency, associated clinicopathological features and impact on survival. J Urol 2004;171:615-20. https://doi.org/10.1097/01.ju.0000106955.19813.f6. 
[15] Siracusano S, Novara G, Antonelli A, Artibani W, Bertini R, Carini M, et al. Prognostic role of tumour multifocality in renal cell carcinoma. BJU Int 2012;110:E443-8. https://doi.org/10.1111/j.1464-410X.2012.11121.x.

[16] Sargin SY, Ekmekcioglu O, Arpali E, Altinel M, Voyvoda B. Multifocality incidence and accompanying clinicopathological factors in renal cell carcinoma. Urol Int 2009;82:324-9.

https://doi.org/10.1159/000209366.
[17] Mano R, Kent M, Larish Y, Winer AG, Chevinsky MS, Hakimi AA, et al. Partial and Radical Nephrectomy for Unilateral Synchronous Multifocal Renal Cortical Tumors. Urology 2015;85:1404-10.

https://doi.org/10.1016/j.urology.2015.02.032.

[18] Schlichter A, Werner W, Wunderlich H, Schubert J. Multifocal renal cell carcinoma - diagnostic value of imaging techniques in vivo and ex vivo. J Urol, suppl 1999;161:168, abstract 647 .

https://www.researchgate.net/publication/246112202. 